\title{
Industrializing Korean Traditional Housing (Hanok) with Hybrid Timber Construction
}

\author{
Youngsoo JUNG ${ }^{*}$, Ikhaeng $\mathrm{LEE}^{2}$, Sungrae $\mathrm{KIM}^{2}$ and Yunsub $\mathrm{LEE}^{3}$ \\ ${ }^{1}$ Professor, Department of Architecture, Myongji University, South Korea \\ ${ }^{2}$ MS candidate, Department of Architecture, Myongji University, South Korea \\ ${ }^{3}$ Research Professor, Department of Architecture, Myongji University, South Korea \\ *Corresponding author's e-mail: yjung97@mju.ac.kr
}

\begin{abstract}
In an attempt to disseminate traditional Korean culture, a comprehensive research has been initiated by Korean government in order to modernize Korean traditional housing (Hanok) with the objectives of improved energy performance and affordable construction cost. This 'Hanok' project encompasses a wide spectrum of housing research including public policies, planning methods, standard design documents, new building materials and methods, construction standards, maintenance manuals, and advanced IT applications in an integrated manner. One of the biggest challenges in this 'Hanok' project was to modernize the 'traditional timber structure' for industrialization, while keeping the traditional way of aesthetic representation. As a solution to meet this complicated requirement, a hybrid timber system was developed by combining traditional methods and industrialized modular members. Different timbers and methods are used together for different part of house elements resulting in cost reduction by $50 \%$ for the timber frame. Major criteria for applying different methods include the aesthetic representation, economy, and deformation behaviour of wood. Automated computer numeric control (CNC) machine, standard 3D-CAD objects, standard classifications, and computer applications were also developed in order to make this hybrid system economically feasible. This paper introduces the hybrid timber system for Hanok along with supportive application systems for industrialization. Three mock-up projects, actually built as part of this research project, are compared and analysed in order to illustrate how the proposed hybrid timber system has evolved during the research and development. Lessons learned and future directions will be also briefly discussed.
\end{abstract}

\section{KEYWORDS}

Modular timber structure, Traditional timber construction, BIM, Industrialization

\section{INTRODUCTION}

Over the decade, there is a highly increasing demand for single family homes in Korean traditional style because the most popular form of housing in Korea has been high-rise apartment complex. This new trend also comes from the overall proliferation of Korean culture including popular music, drama, and food. However, the barriers to disseminating traditional Korean housing (Hanok) include extremely high construction cost, low energy performance, and accommodating modern life-style. 
In order to address these problems, a comprehensive research has been initiated by Korean government to modernize Korean traditional housing (Hanok) with the objectives of improved energy performance and affordable construction cost (Kim et al. 2014). This 'Hanok' project encompasses a wide spectrum of housing research including public policies, planning methods, standard design documents, new building materials and methods, construction standards, maintenance manuals, and advanced IT applications in an integrated manner.

In terms of construction cost and energy performance, one of the biggest challenges in this 'Hanok' research project was to modernize the 'traditional timber structure' for industrialization, while keeping the traditional way of aesthetic representation. As a solution to meet this complicated requirement, a hybrid timber system was developed by combining traditional methods and industrialized modular members. Different timbers and methods are used together for different part of house elements. Three mock-up (testbed) projects, actually built as part of this research project, are compared and analysed in order to illustrate how the proposed hybrid timber system has evolved during the research and development. This paper introduces the distinctive requirements and solutions for modernized Hanok development focusing on the wood frames.

\section{STNADARD CLASSIFICATIONS: HANCLASS}

For the purpose of integrating and analysing the whole processes and data from the industry perspective, it is of great importance to develop a standard classification system and project numbering system (PNS). A comprehensive numbering system entitled HanClass was developed (Jung et al. 2012) for modernized Hanok as described in Table 1.

Table 1. Standard Classifications and Numbering Systems for Hanok (Jung et al. 2013)

\begin{tabular}{|c|c|c|c|}
\hline Level I & Level II & Level III & Remarks \\
\hline \multirow{19}{*}{ 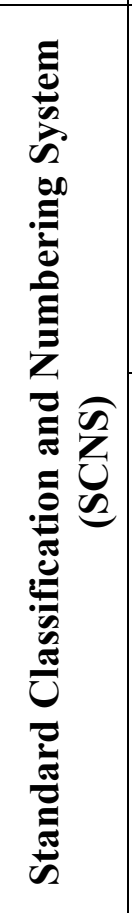 } & \multirow{8}{*}{$\begin{array}{l}\text { Standard } \\
\text { Classifications } \\
(\mathbf{C L N})^{*}\end{array}$} & (CLF) Facility Facet & e.g. Building, Airport \\
\hline & & (CLS) Space Facet & e.g. Office, Bed room \\
\hline & & (CLE) Element Facet & e.g. Column, Beam \\
\hline & & (CLW) Work Section Facet & e.g. Steel structure, Piping \\
\hline & & (CLM) Construction Material/Assembly Facet & e.g. Re-bar, Concrete \\
\hline & & (CLA) Construction Aid Facet & e.g. Wood form, Crane \\
\hline & & (CLG) Management Facet & e.g. Schedule, Contracting \\
\hline & & (CLP) Attribute and Property Facet & e.g. Heat transmission \\
\hline & \multirow{11}{*}{$\begin{array}{c}\text { Project } \\
\text { Numbering } \\
\text { Systems } \\
\text { (PNS) }\end{array}$} & (GBS) Geometry Breakdown Structure ** & Multi-facet for 3D design \\
\hline & & (WBS) Work Breakdown Structure & Multi-facet for scheduling \\
\hline & & $(\mathrm{CBS})$ Cost Breakdown Structure & Multi-facet for cost control \\
\hline & & (EBS) Equipment Breakdown Structure & Multi-facet for procurement \\
\hline & & (OBS) Organization Breakdown Structure & Multi-facet for participants \\
\hline & & (RBS) Risk Breakdown Structure & Multi-facet for risk \\
\hline & & (MBS) Measurement Method Breakdown & Multi-facet for estimating \\
\hline & & (SBS) Specifications Breakdown Structure & Multi-facet for specs \\
\hline & & (DBS) Drawing Breakdown Structure & Multi-facet for drawings \\
\hline & & (PBS) Physical Breakdown Structure & Single facet numbering \\
\hline & & (FBS) Functional Breakdown Structure & Single facet numbering \\
\hline
\end{tabular}

* Eight facets defined by ISO (1994), ** Patented by Myongji University (US Patent No.: 9,141,925) 
It has two major parts. The first part is standard classifications that categorize relevant items and specify a unique number to each item (for example, MasterFormat (2012), Uniclass (1997), and OmniClass (2006)). Each master list of HanClass has somewhat different structure, however, all of them basically follows the international framework set out by ISO TR 14177 (ISO 1994) which was later established as ISO 12006-2. The second part is project numbering systems (PNS). Though single numbering system (e.g. WBS) can be utilized universally for many different construction business functions (e.g. cost, schedule, materials, etc.), it is extremely difficult to satisfy complex managerial requirements (Jung et al. 2013) of many different functions with one or two numbering systems. It is also generally recognized that a PNS may differ from project to project. However, it was possible to define standard PNS because the Hanok project is very specific to single type of building. Table 1 presents the overall structure of standard classifications and numbering systems (SCNS) for Hanok developed by Jung et al. (2013).

\section{STRUCTURE AND COMPONENTS OF HANOK}

Basically, Hanok is a timber frame structure (as appose to light-frame wood structure) which has timber columns and beams. Traditional Hanok frames use delicate and tight fitting joints, which makes this timber structure as a semi-rigid frame. However, it is extremely costly to perform in modern construction projects (Kim et al. 2014). Another distinct characteristic of Hanok is that the columns are exposed along with wall panels, resulting in vulnerable joints between columns and walls. Deformation of timber columns often cause cracks in these joints, resulting in air infiltration and energy loss.

Table 2. Timber Frames of Three Testbed Projects

\begin{tabular}{|c|c|c|c|}
\hline Description & $\begin{array}{c}\text { Traditional } \\
\text { Hanok (Project 1) }\end{array}$ & $\begin{array}{c}\text { Modernized } \\
\text { Hanok (Project 2) }\end{array}$ & $\begin{array}{c}\text { Modernized } \\
\text { Hanok (Project 3) }\end{array}$ \\
\hline Year Built & 2012 & 2013 & 2016 \\
\hline Total floor area $\left(\mathrm{m}^{2}\right)$ & 70 & 140 & 940 \\
\hline Cost - Total Cost* $\left(\$\right.$ per $\left.\mathrm{m}^{2}\right)$ & 3,200 & 1,800 & 1,800 \\
\hline Cost - Timber Frame $\left(\$\right.$ per $\left.\mathrm{m}^{2}\right)$ & 1,050 & 590 & 510 \\
\hline Cost - \% of Timber Frame & $33 \%$ & $33 \%$ & $29 \%$ \\
\hline Cost - Productivity (m³/MD) & 0.42 & 0.87 & 0.83 \\
\hline Material - Timber $\left(\mathrm{m}^{3}\right.$ per $\left.\mathrm{m}^{2}\right)$ & 0.22 & 0.18 & 0.15 \\
\hline Material - Solid/Glulam & Solid Wood & Solid + Glulam & Solid + Glulam \\
\hline Method - Timber/Light Weight & $\begin{array}{l}\text { Traditional } \\
\text { (Timber) }\end{array}$ & $\begin{array}{c}\text { Modernized } \\
(\text { Timber + Light W) }\end{array}$ & $\begin{array}{c}\text { Modernized } \\
(\text { Timber + Light W) }\end{array}$ \\
\hline Method - Frame Joint & Mortise and Tenon & $\begin{array}{l}\text { Mortise and Tenon } \\
+ \text { Metal Connectors }\end{array}$ & $\begin{array}{l}\text { Mortise and Tenon } \\
+ \text { Metal Connectors }\end{array}$ \\
\hline Method - Trimming & Manual, On-site & $\begin{array}{l}\text { Manual, On-site } \\
+ \text { Prefabricated }\end{array}$ & $\begin{array}{l}\text { Manual, On-site } \\
+ \text { Prefabricated }\end{array}$ \\
\hline Method - Roof Structure & Wood + Mud & Wood & Wood \\
\hline
\end{tabular}

* Total cost does not include landscape, outside utility, overhead, and profit. 
Table 3. Building Methods for Three Testbed Projects

\begin{tabular}{|c|c|c|c|}
\hline Element & $\begin{array}{c}\text { Traditional } \\
\text { Hanok (Project 1) }\end{array}$ & $\begin{array}{c}\text { Modernized } \\
\text { Hanok (Project 2) }\end{array}$ & $\begin{array}{c}\text { Modernized } \\
\text { Hanok (Project 3) }\end{array}$ \\
\hline $\begin{array}{l}\text { Building } \\
\text { View }\end{array}$ & & & \\
\hline \multirow[t]{2}{*}{$\begin{array}{l}\text { Timber } \\
\text { Fame }\end{array}$} & & & \\
\hline & Fitting Joint & Metal Joint & Metal Joint \\
\hline \multirow[t]{2}{*}{ Wall } & & & \\
\hline & Wet Method & Dry Method & Dry Method \\
\hline \multirow[t]{2}{*}{ Windows } & & & \\
\hline & On-site Fabrication & Fabricated Windows & Fabricated Windows \\
\hline \multirow[t]{2}{*}{$\begin{array}{c}\text { Roof } \\
\text { Structure }\end{array}$} & & & \\
\hline & On-site Cutting & Pre-cut Members & Pre-cut Members \\
\hline \multirow[t]{2}{*}{$\begin{array}{l}\text { Roof Tile } \\
\text { Setting }\end{array}$} & & & \\
\hline & Mud-bed Clay Tile & Plastic Tile & Modified Clay Tile \\
\hline
\end{tabular}


In order to address this issue, new Hanok utilizes modernized framing methods including factory pre-cut timber members (solid and glulam), light frames, as well as traditional methods for different building elements. For example, testbed 'Project 3' in Table 2 applied the traditional method for rafters to easily represent traditional aesthetics in roof lines, light frames for walls to reduce time and cost, glulam pre-cut timbers for outer column to minimize deformation, and solid pre-cut timbers for inner columns to reduce cost. Note that glulam columns are more expensive and outperforms the solid ones. Again, selecting a specific method was evaluated in terms of 'construction cost' and 'energy performance'. Even within the roof structure, traditional and modern methods were mixed together. For example, rafters were built in a traditional way, but roof panels by a modernized method. Some parts of roof structure were made with light-frame wood, where those are not visually exposed.

For the purpose of extensive information exchange in an automated way, this research developed a standard numbering system introduced in Table 1, and this numbering system has been fully applied to all testbed construction projects. Therefore, it is possible to compare cost, schedule, and other measures between different testbed projects by the same work section or element. As shown in Table 2, the cost for timber frame of Project 3 (modernized Hanok, 510 dollars per floor area square meter) was reduced by half when comparing with that of Project 1 (traditional Hanok, 1,050 dollars per square meter) while significantly enhancing energy performance and durability. The quantity of timber materials required for Project 3 was also reduced by $32 \%$ ( 0.22 to 0.15 cubic meters per floor area square meter).

Even though it was successful to significantly reduce the overall cost of modernized Hanok, unit price of 1,800 dollars per square meter is still expensive comparing to general housing types. Therefore, it is considered to use another type of hybrid systems. Namely, using light-frame structure or combing with steel structure are possible solutions. This change of structural system may bring up a tough issue how Korean tradition can be secured or embedded into the new design with hybrid systems.

\section{INDUSTRIALIZING TIMBER CONSTRUCTION FOR HANOK}

Building materials and methods developed for Hanok need to be industrialized in order to boost practical dissemination. The tools for industrialization may include standardized drawings, factory fabrication, and standards for supply chain management. Several different applications were developed based on the information exchange standards described in Table 1. Firstly, as for the standard drawings, standard 3D-CAD objects were developed to easily create complex shapes of drawings, and standard 2D drawings and specifications were published. Automated CAD systems for modular design was developed as well. As an interesting tool for prefabrication, an automated computer numeric control (CNC) machine for trimming asymmetric rafters (Hong et al. 2013) was developed to reduce the high cost of large number of rafters required.

Another important aspect of Hanok industrialization is the standard information for materials, cost, and schedule for supply chain management. Several different web pages for this purpose were provided for unspecified users even including individual homeowners. 
The first example (software.cicms.org) has three major functions; schedule generation, cost estimating, and automated cost-schedule integration (EVMS). Web-based simple scheduling system was developed by using durations from the historical data. Users can easily modify on the web to fit in with their own projects and download them in a spread sheet format (MS Excel). Cost estimating function allows to generate construction budget items based on standard unit price. Finally, by uploading the cost and schedule data back to the website, the system automatically creates EVMS calculation for each schedule activity. Furthermore, by combining 3D-CAD and EVMS, a 5D-CAD simulation using GBS (in Table 1, US Patent No. 9,141,925 by Myongji Univ.) can be automatically performed.

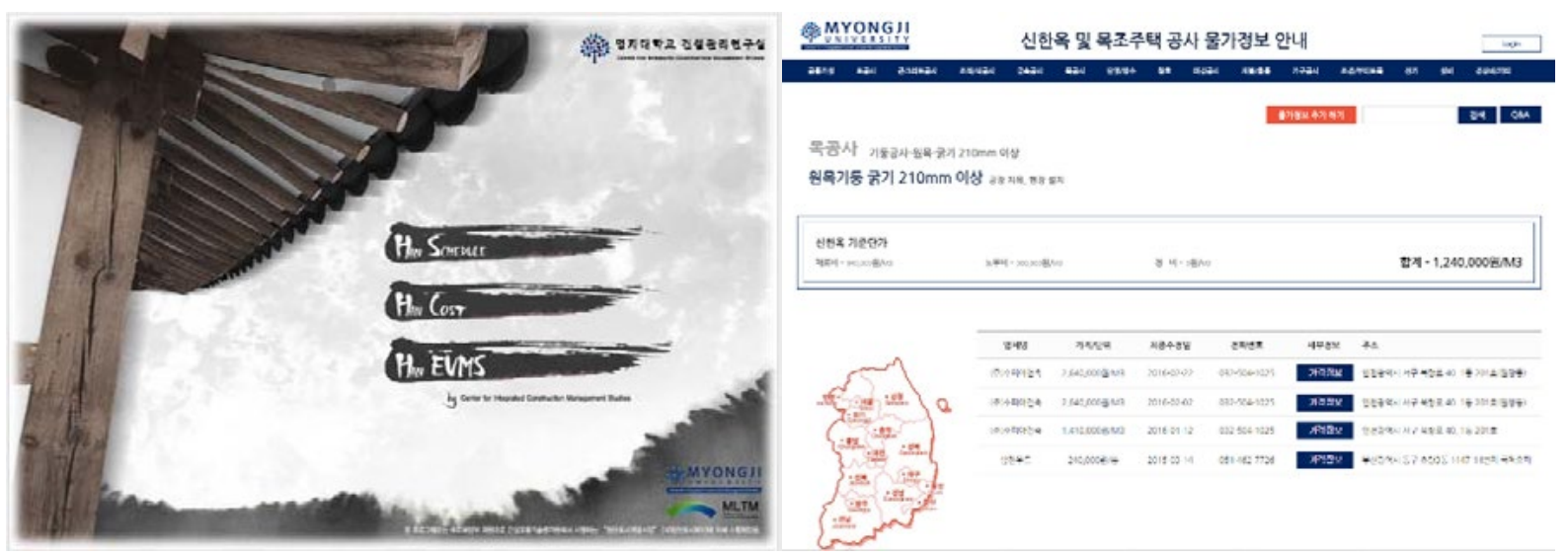

Figure 1. Web-based Programs for Hanok (software.cicms.org \& costdata.cicms.org)

The second one provides with detail cost information (including prices for labour, material, and equipment). It is different from existing cost data sets, because it has standard cost data as well as suppliers' product information with suggested price for each standard work item. Standard price is used as a guideline and initially determined by the cost data from testbed projects. Suppliers can freely upload their product and price information to this website.

Besides the tools above-mentioned, many different regulations, technical guides, specifications, and standard documents for 'Hanok' have been researched and published to support industrialization. This effort encompasses the disciplines of architectural design, structural, environmental, and construction engineering. In the next step of this research, it is also planned to establish a 'production and distribution' system in order to better supply materials and equipment. It is noteworthy that the standard classifications listed in Table 1 has contributed enormously throughout the entire process of this effort. This fact supports the importance of standard classifications in the industrialization.

\section{CONCLUSIONS}

Increasing interests in traditional and environment friendly Korean housing have motivated active researches to modernize traditional Korean housing (Hanok). This paper outlines the research efforts in industrializing 'modernized Hanok', especially focused on timber structure. 
In order to meet the objectives of 'affordable building cost' and 'improved energy performance', traditional timber structure has been redesigned by using a hybrid application of timber frame and light frame together with different joints and materials. Different methods and materials were selected for different elements to meet the objectives. It was successful to significantly reduce the cost by about $40 \%$ (total construction cost) and to enhance energy performance to an acceptable level. However, further development is anticipated to expand into other types of hybrid including steel structure. Current cost of 1,800 dollars per square meter is still expensive compared to general housing. Nevertheless, it is encouraging that a significant cost reduction has been achieved while keeping the traditional style and heritage.

It is strongly stressed that supporting infrastructure including standard classification, standard design documents, standard building materials and methods, computer application systems, and materials distribution system is critical part for successful industrializing.

\section{ACKNOWLEDGEMENTS}

This study was supported by the Ministry of Land, Transport and Maritime Affairs (MLTM) of the Korean Government under Grant No. 14AUDP-B070934-02 and also supported by "Basic Science Research Program" through the National Research Foundation of Korea (NRF) funded by the Ministry of Science, ICT, and Future Planning (MSIP) under Grant no. 2014R1A2A2A01006984.

\section{REFERENCES}

Hong, S., Ullah, F., Lee, G., and Park, K. (2013). "Development of Rafter Processing Machine and Simulation Verification", Transactions of the Society of CAD/CAM Engineers, 18(2), 148-154.

Jung, Y., Kim, M., and Lee, Y. (2013). "Unified Geometry Breakdown Structure (uGBS) for BIM: Variables for Theory and Implementation", Proceedings of 30th International Conference on Applications of IT in the AEC Industry, CIB W78, Beijing, China, 183-189.

Jung, Y., Kim, W. and Ha, J. (2012). "Standard Classifications and Project Numbering System for Integrated Construction Management of Modernized Korean Housing (Hanok)". Transactions of the Society of CAD/CAM Engineers, 17(4), 225-233.

Kim, M., Kim, H., Ryu, J. and Jung, Y. (2014). "New Building Materials and Methods for Modernized Korean Housing (Hanok)", Korean Journal of Construction Engineering and Management, 15(2), 23-32.

MasterFormat. (2012). MasterFormat: Master List of Numbers and Titles for the Construction Industry. The Construction Specifications Institute (CSI), Alexandria, VA, USA.

OmniClass (2006). OmniClass: Introduction and User's Guide, The Construction Specifications Institute (CSI), Alexandria, VA, USA.

Uniclass (1997). Uniclass: Unified classification for the construction industry, Royal Institute of British Architects (RIBA) Publications, London, UK. 